\title{
"The efficiency of Islamic banks versus conventional banks: an empirical study of an emerging economy"
}

\begin{tabular}{|c|c|c|}
\hline AUTHORS & \multicolumn{2}{|c|}{$\begin{array}{l}\text { Hassan M. Hafez } \\
\text { Mona Halim (D https://orcid.org/0000-0001-9075-2801 }\end{array}$} \\
\hline ARTICLE INFO & \multicolumn{2}{|c|}{$\begin{array}{l}\text { Hassan M. Hafez and Mona Halim (2019). The efficiency of Islamic banks versus } \\
\text { conventional banks: an empirical study of an emerging economy. Banks and } \\
\text { Bank Systems, 14(2), 50-62. doi:10.21511/bbs.14(2).2019.05 }\end{array}$} \\
\hline DOI & \multicolumn{2}{|c|}{ http://dx.doi.org/10.21511/bbs.14(2).2019.05 } \\
\hline RELEASED ON & \multicolumn{2}{|l|}{ Friday, 17 May 2019} \\
\hline RECEIVED ON & \multicolumn{2}{|l|}{ Sunday, 17 March 2019} \\
\hline ACCEPTED ON & \multicolumn{2}{|l|}{ Monday, 01 April 2019} \\
\hline & \multicolumn{2}{|l|}{$(c)$ EY } \\
\hline LICENSE & \multicolumn{2}{|c|}{$\begin{array}{l}\text { This work is licensed under a Creative Commons Attribution } 4.0 \text { International } \\
\text { License }\end{array}$} \\
\hline JOURNAL & \multicolumn{2}{|l|}{ "Banks and Bank Systems" } \\
\hline ISSN PRINT & \multicolumn{2}{|l|}{$1816-7403$} \\
\hline ISSN ONLINE & \multicolumn{2}{|l|}{$1991-7074$} \\
\hline PUBLISHER & \multicolumn{2}{|c|}{ LLC "Consulting Publishing Company "Business Perspectives" } \\
\hline FOUNDER & \multicolumn{2}{|c|}{ LLC "Consulting Publishing Company "Business Perspectives" } \\
\hline$\sigma^{\circ}$ & 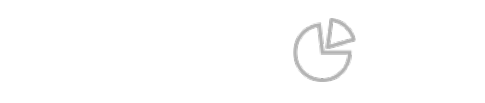 & $\begin{array}{l}\Xi=こ \\
\text { 三ここ }\end{array}$ \\
\hline NUMBER OF REFERENCES & NUMBER OF FIGURES & NUMBER OF TABLES \\
\hline 18 & 1 & 13 \\
\hline
\end{tabular}

(C) The author(s) 2022. This publication is an open access article. 


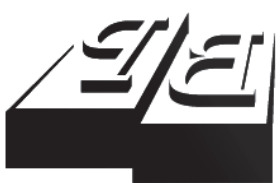

BUSINESS PERSPECTIVES

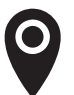

LLC "CPC "Business Perspectives" Hryhorii Skovoroda lane, 10, Sumy, 40022, Ukraine

www.businessperspectives.org

Received on: $17^{\text {th }}$ of March, 2018 Accepted on: $1^{\text {st }}$ of April, 2019

(C) Hassan M. Hafez,

Mona Halim, 2019

Hassan M. Hafez, Assistant Professor, Canadian International College, Egypt.

Mona Halim, Assistant Professor of Economics, Administrative and Financial Sciences Department, Community College Dammam, Imam Abdul Rahman Bin Faisal University, Saudi Arabia.

\section{() (i)}

This is an Open Access article, distributed under the terms of the Creative Commons Attribution 4.0 International license, which permits unrestricted re-use, distribution, and reproduction in any medium, provided the original work is properly cited.
Hassan M. Hafez (Saudi Arabia), Mona Halim (Saudi Arabia)

\section{THE EFFICIENCY OF ISLAMIC BANKS VERSUS CONVENTIONAL BANKS: AN EMPIRICAL STUDY OF AN EMERGING ECONOMY}

\begin{abstract}
The purpose of this study is to investigate the efficiency of two different banking systems operating in Egypt (Islamic versus conventional banks). A sample of 35 banks has been used to examine the technical efficiency before and after the financial crisis using data envelopment analysis model. Evaluating the technical efficiency of Egyptian banks will enable policymakers to support which banking system is more efficient to facilitate the financial inclusion and enhance the economic development.

Before the financial crisis, conventional banks outperformed conventional banks with Islamic windows and Islamic banks, scale technical efficiency outperformed pure technical efficiency when analyzing conventional banks and conventional banks with Islamic windows. In terms of Islamic banks, pure efficiency outperformed scale efficiency. After the financial crisis, technical efficiency of all banks decreased. However, pure technical efficiency of Islamic banks has improved as a result of the quality of management and outperformed both conventional banks and conventional banks with Islamic windows. These results imply that Islamic banks have not been affected by the financial crisis. Therefore, the increased adoption and support of the Islamic banks in Egypt is addressed to develop the economy and push forward entrepreneurship projects, support the financial inclusion and the informal economy integration.
\end{abstract}

\section{Keywords}

JEL Classification

\section{banks, technical efficiency}

\section{INTRODUCTION}

The financial crisis opened the door for raising many questions regarding the current global financial system led by conventional banks to adopt the concept of interest rate in all financial transactions. Also, if the business model of conventional banks has contributed as a major factor to the global financial crisis. Accordingly, many researchers begun to shed light on various aspects of Islamic finance as an alternative to traditional finance offered by conventional banks. Two important factors support the business model of the conventional banks: the use of interest rate as a market indicator, or in the form of return when investing funds. And all financial transactions of conventional banks contain a degree of risk and uncertainty. Interest rate can be viewed as a mechanism of pricing in which funds can be allocated. Conventional banks introduce several financial products to suit the finance requirements of individuals and businesses. Products offered by conventional banks include a degree of uncertainty, so an interest rate is calculated as the cost of borrowing or remuneration. The rise in interest rate is a compensation to the high degree of uncertainty and a low interest rate be a low risk or uncertainty. Islamic finance refers to those activities that comply with Islamic law (Shari'ah). Shari'ah prohibits usury or interest paid to all loans. Usury is prohibited and 
charging and receiving the interest rate on all financial transactions are not allowed. Trading in pork or pork products as well as intoxicants and game of chance is prohibited as well. Moreover, all lines of business relating to these prohibited activities are also prohibited. Therefore, conventional banks do not meet the principles of Islamic law and the interest rate is the main catalyst for them. The operating model in Islamic finance is based on the rates of return achieved by Shari'ah-compliant finance and investment activities, which are related to the profits generated by the activities of economic sectors associated with them and are not entirely dependent on interest rates. Terms and conditions contained in contracts related to those services and activities should not include any element of interest or uncertainty. The philosophy of the Islamic finance is stemmed on the principle of the risk sharing rather than risk transfer. Risk is the main driver of profits or losses, and since risk is shared then profits and losses should be shared too. Shared risk leads to shared economy and this definitely will be significant to the stability and welfare of the economy.

\section{A SINGLE VERSUS DUAL SYSTEM}

There are two types of financial systems for banks, namely single system and dual banking system. In a single system, all financial transactions must be Shariah compliant. However, the dual banking system allows for the existence of both the conventional and the Islamic banking, with laws and regulations governing their work simultaneously. Iran, Sudan and Pakistan were among the first countries to adopt a single banking system. This means they offer exclusively Shari'ah complaint financial products and services. This resulted in establishing a single Islamic financial institution. On the other hand, other countries, including Bahrain, Malaysia, United Arab Emirates, Kuwait and Egypt, follow a dual banking system. In Egypt, windows or counters have been established as part of conventional banks to offer financial products and services according to Shari'ah compliant.

Figure 1 illustrates in greater detail the evolution of deposits, loans and assets values to Islamic banks during the study period.

\section{LITERATURE REVIEW}

According to Berger and Humphrey (1997), there are 130 studies on efficiency measures for banks. These studies have been applied to American banks and a number of other developed countries. Yet, there are still very few studies to meas-

Table 1. Total assets, deposits and loans for the years 2003 to 2017

\begin{tabular}{|c|c|c|c|c|c|c|}
\hline \multicolumn{4}{|c|}{ Conventional banks } & \multicolumn{3}{|c|}{ Islamic banks } \\
\hline Year & $\begin{array}{l}\text { Deposits in } \\
\text { LE, } \mathrm{mln}\end{array}$ & $\begin{array}{l}\text { Assets in } \\
\text { LE, } \mathrm{mln}\end{array}$ & $\begin{array}{l}\text { Loans in } \\
\text { LE, mln }\end{array}$ & $\begin{array}{c}\text { Deposits in LE, } \\
\mathrm{mln}\end{array}$ & $\begin{array}{l}\text { Assets in } \\
\text { LE, mln }\end{array}$ & $\begin{array}{l}\text { Loans in } \\
\text { LE, } \mathrm{mln}\end{array}$ \\
\hline 2003 & 403.144 & 577.938 & 284.722 & 60,472 & 44,912 & 2,847 \\
\hline 2004 & 461.697 & 633.436 & 296.199 & 69,255 & 46,345 & 2,962 \\
\hline 2005 & 519.697 & 705.146 & 308.195 & 77,947 & 50,617 & 3,082 \\
\hline 2006 & 568.841 & 761.562 & 324.041 & 85,326 & 52,341 & 3,240 \\
\hline 2007 & 605,460 & 882,249 & 339,236 & 97,493 & 55,674 & 3,427 \\
\hline 2008 & 635,119 & $1,022,899$ & 268,003 & 98,080 & 60,412 & 3,717 \\
\hline 2009 & 508,810 & $1,027,390$ & 386,280 & 101,790 & 64,603 & 3,902 \\
\hline 2010 & 583,185 & $1,150,419$ & 403,675 & 102,915 & 70,236 & 4,078 \\
\hline 2011 & 616,146 & $1,191,130$ & 439,722 & 108,732 & 78,560 & 4,442 \\
\hline 2012 & 661,135 & $1,281,218$ & 360,533 & 116,671 & 84,942 & 3,642 \\
\hline 2013 & 762,005 & $1,373,636$ & 384,001 & 134,472 & 90,213 & 3,879 \\
\hline 2014 & 883,733 & $1,425,642$ & 414,187 & 155,953 & 91,231 & 4,184 \\
\hline 2015 & 995,813 & $1,502,324$ & 524,233 & 188,765 & 102,231 & 7,237 \\
\hline 2016 & $1,313,915$ & $1,640,211$ & 609,281 & 211,904 & 105,543 & 9,235 \\
\hline 2017 & $1,432,689$ & $1,723,012$ & 823,456 & 232,087 & 151,923 & 12,723 \\
\hline
\end{tabular}




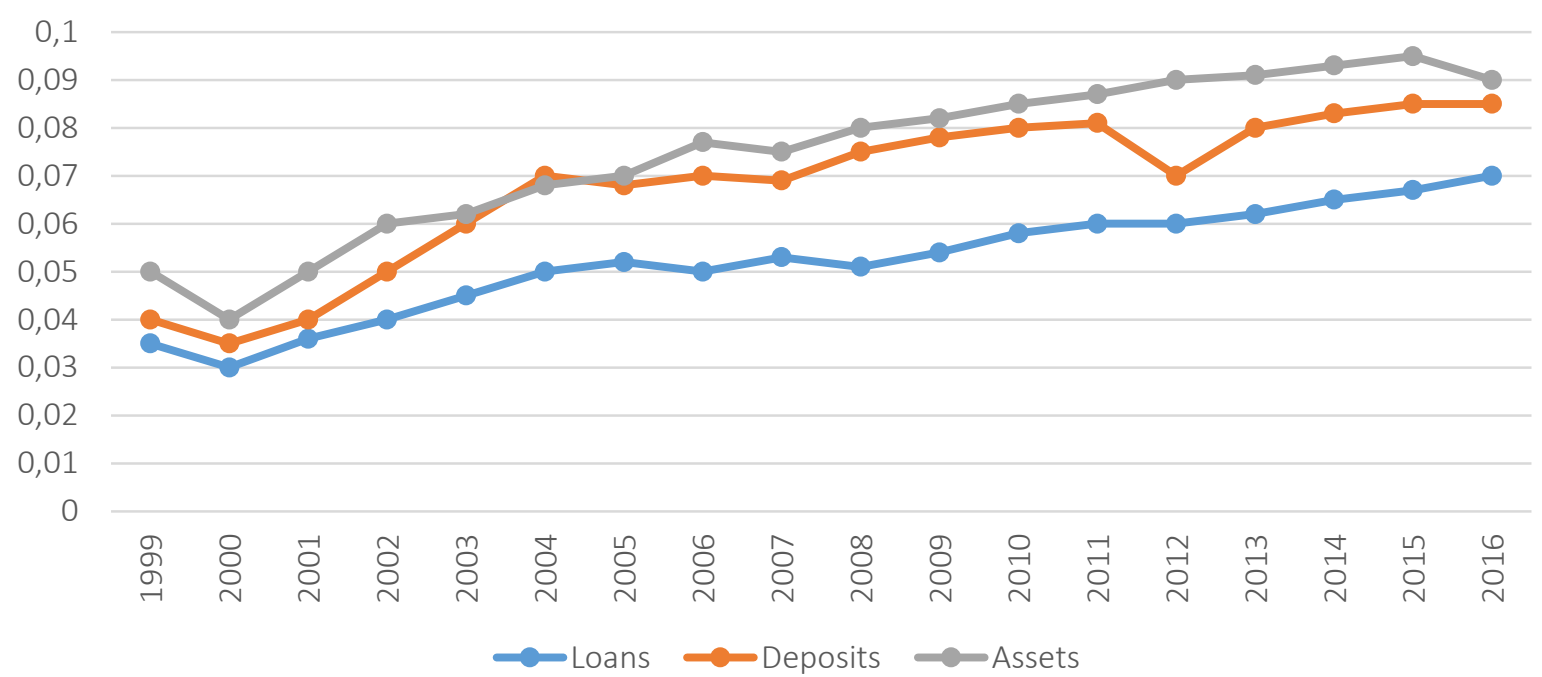

Figure 1. Islamic finance contributions to the banking sector in Egypt

ure efficiency at the level of Islamic banks. Many researchers used financial analysis to compare efficiency between conventional and Islamic banks. Trad and Trabelsi (2017) examined profitability and risk on a sample of 94 Islamic banks operating in 18 countries from 2006 to 2013. They used return on equity and return on assets indicators to measure profitability, credit risk and insolvency risk to measure the risk. Results revealed that capital is the main driver to maximizing stability, profitability and reducing the credit risk. Islamic banks in GCC are more profitable, solvent and less risky than Islamic banks operating in the South East Asian region.

Recently, the focus has been on studying the efficiency of banks through the application of stochastic frontier analysis (SFA) and Nonparametric approaches such as DEA. Srairi (2010) examined profit and cost efficiency using a sample of 71 banks in the GCC. Results indicated that conventional banks outperformed Islamic banks. Yudistira (2004) examined country-specific factors and assured that Islamic banks are less efficient than conventional banks, since Islamic banks are affected only by country-specific factors. Similarly, Abdul-Majid et al. (2010) proved that conventional banks achieved lower return than Islamic banks through the application of output distance function.

Gishkori and Ullah (2013) examined technical efficiency of Islamic and conventional banks operating in Pakistan from 2007 to 2011. Results indi- cated that technical efficiency varies between the two regimes. In conventional banks, it depends on pure technical inefficiency, while in Islamic banks, it attributes to the bank scale. Ahmed and Abdel Rahman (2012) proved that conventional banks outperformed Islamic banks by using all efficiency measures. This was attributed to the superior of conventional banks in terms of technology and management efficiency. Kamuradin et al. (2014) investigated efficiency of revenue on a sample of 27 Islamic banks and 47 conventional banks operating in the GCC from 2007 to 2011 using data envelopment analysis intermediation technique. Results indicated that conventional banks outperformed Islamic ones. While Yehya et al. (2012) proved that there are no significant differences when applying to banks operating in Malaysia. Abdul-Majid, Saal and Battisti (2009) compared Islamic and conventional banks from an efficiency perspective applying on a sample of banks operating in 10 countries from 1996 to 2002. They applied the technique of output distant by obtaining an efficiency measure. Results concluded that Islamic banking appears to be associated with higher input usage. There are statistically significant differences in inefficiency. Banks in Sudan and Yemen are among those with the highest levels of inefficiency, while banks in Bahrain are among the countries with the lowest levels of inefficiency. Banks exhibit relatively strong returns to scale except for Sudan, although Islamic banks have moderate higher returns to scale than conventional banks, because Islamic banks benefit from the increased scale. 
Abdul-Wahab and Haron (2017) examined technical, pure and scale efficiency for a sample of 15 banks operating in Qatar from 2007 to 2011 using data envelopment analysis and Malmquist productivity index to determine sources of productive efficiencies. Results indicated that Islamic banks outperformed conventional banks in terms of scale efficiency, whereas conventional banks outperformed Islamic banks when it comes to technical and pure technical efficiency.

\section{METHODOLOGY}

\subsection{Sample and data}

The study sample has been divided into three groups: Islamic, conventional, and conventional banks with Islamic windows. Bank scope data base and the website of each bank are used to obtain banks' balance sheets and income statements.

\subsection{Model specification to measure economic efficiency}

There are two main approaches that are mostly used to determine output and input variables. The production approach founded by Benston (1965) and the intermediation approach founded by Sealy and Lindley (1977). Sufian et al. (2013) stated that both approaches apply traditional microeconomics theory of banking, the linear programming method is used to construct a non-parametric piecewise surface (frontier) over the data to compute efficiencies relative to its surfaces. Over the last years, frontiers have been estimated using two common methods; econometric models and mathematical programming, namely DEA and Stochastic frontier. Farrell (1957) defined a simple measure of firm efficiency, which is based on multiple inputs. The economic efficiency of bank consists of two components: technical efficiency, which reflects the ability of a bank to maximal output from a given set of inputs, and allocative efficiency reflecting the ability of a bank to use an input in optimal proportions. Those two measures are combined together to provide a measure of total efficiency.

The technical efficiency (TE) of a bank can be expressed by the ratio

$$
T E_{1}=0 Q / 0 P
$$

which is equal to $1-(Q P / O P)$.

It will always take a value between one and zero. The allocative efficiency of a bank operating at $p$ is defined as

$$
A E_{1}=0 R / 0 Q .
$$

In practice, the production function of the fully efficient bank is not known. Therefore, it should be estimated through a number of observations. The total economic efficiency (EE) is defined to be the ratio

$$
E E_{1}=0 R / 0 P \text {. }
$$

The product of technical and allocative efficiency provides the overall economic efficiency of the banks as follows:

$$
\begin{aligned}
& T E_{1} \times A E_{1}=(0 Q / 0 P) \times(0 R / 0 Q)= \\
& =(0 R / 0 P)=E E_{1} .
\end{aligned}
$$

The CSR model is widely used based on input orientation concept to allow for comparing between small, medium and large banks. This is in line with the study community represented by banks operating in Egypt.

Assume there are data on $K$ inputs and $M$ outputs on each of $N$ banks or DMU's as they are defined in the DEA literature. For the $i$-th DMU, these could be represented by the vectors $x_{i}$ and $y_{i}$, respectively. The $K \mathrm{x} N$ input matrix, $X$, and the $M$ $\mathrm{x} N$ output matrix, $Y$, represent the data of all $\mathrm{N}$ DMU's (Coelli, 1996).

For each bank, one would like to obtain a measure of the ratio of all outputs over all inputs such as $\left(o^{\prime} y_{i} / n^{\prime} x_{i}\right)$, where $o$ is an $M \times 1$ vector of outputs weights and $n$ is a $K \mathrm{x} 1$ vector of input weights. In order to select optimal weights, the mathematical programming problem is specified. The technical efficiency of a bank will be calculated by taking the highest value of the weighted outputs into the weighted inputs. In that way, multiple inputs and outputs of decision-making units are reduced to one input and output by optimal weighting. 


$$
\operatorname{Max}_{o, n}\left(o^{\prime} y_{i} / n^{\prime} x_{i}\right)
$$

Subject to:

$$
\left(o^{\prime} y_{i} / n^{\prime} x_{i}\right) \leq 1, \quad j=1,2, \ldots, n, \quad o, n \geq 0 .
$$

This involves finding values of $o$ and $n$ so that the efficiency measure of the $i$-th bank is maximized. This is subject to the constraints that all efficiency measures must be less or equal to one and therefore providing to an infinite number of solutions. To avoid this, one can impose a constant constraint, that is $n^{\prime} x_{i}=1$, which provides the following formula:

$$
\operatorname{Max}_{\mu, p}\left(\mu^{\prime} y_{i}\right)
$$

Subject to:

$$
\begin{aligned}
& p^{\prime} x_{i}=1, \quad\left(\mu^{\prime} y_{i}-p^{\prime} x_{i}\right) \leq 1, \quad j=1,2, \ldots, N, \\
& \mu, p \geq 0,
\end{aligned}
$$

where the notation changes from $o$, and $n$ to $\mu$ and $p$ reflect the transformation. This form is known as the multiplier form of the linear programming problem. An equivalent envelopment of the linear programming problem can be derived as follows:

$$
\operatorname{Min}_{\theta, \lambda} \theta
$$

Subject to:

$$
-y_{i}+Y \lambda \geq 0, \quad \theta x_{i}-X \lambda \geq 0, \quad \lambda \geq 0,
$$

where $\theta$ is a scalar and $\lambda$ is an $N \mathrm{x} 1$ vector of constant. This envelopment form involves fewer constraints than the multiplier $(K+M<N+1)$, and hence it is generally the preferred form to solve. The value of $\theta$ is the efficiency score for the $i$-th bank. It will satisfy $\theta \leq 1$, with a value of 1 indicating a point on the frontier and therefore a technically efficient bank (Farrell, 1957). It must be solved $\mathrm{N}$ times according to the number of banks included in the model.

\section{EFFICIENCY MEASURES BEFORE THE FINANCIAL CRISIS}

\begin{tabular}{|c|c|c|c|c|c|}
\hline Year & $\begin{array}{c}\text { Outputs } \\
\text { Total loans }\end{array}$ & Mean & Min & Max & SD \\
\hline 2003 & $\begin{array}{l}\text { Total loans } \\
\text { Income }\end{array}$ & $\begin{array}{l}8,134 \\
443.7\end{array}$ & $\begin{array}{c}2,033 \\
80\end{array}$ & $\begin{array}{c}52,871 \\
2,215\end{array}$ & $\begin{array}{c}14,315.02 \\
645.1\end{array}$ \\
\hline 2004 & $\begin{array}{l}\text { Total loans } \\
\text { Income }\end{array}$ & $\begin{array}{l}8,463 \\
413.8\end{array}$ & $\begin{array}{c}2,116 \\
86.4\end{array}$ & $\begin{array}{c}59,241 \\
2,478\end{array}$ & $\begin{array}{c}15,760 \\
672.6\end{array}$ \\
\hline 2005 & $\begin{array}{l}\text { Total loans } \\
\text { Income }\end{array}$ & $\begin{array}{l}8,806 \\
402.3\end{array}$ & $\begin{array}{l}2,302 \\
115.7\end{array}$ & $\begin{array}{c}70,448 \\
2,715\end{array}$ & $\begin{array}{c}19,825 \\
650.0\end{array}$ \\
\hline 2006 & $\begin{array}{l}\text { Total loans } \\
\text { Income }\end{array}$ & $\begin{array}{l}9,259 \\
541.9\end{array}$ & $\begin{array}{l}2,314 \\
118.9\end{array}$ & $\begin{array}{c}76,047 \\
2,652\end{array}$ & $\begin{array}{l}21,231 \\
711.80\end{array}$ \\
\hline 2007 & $\begin{array}{l}\text { Total loans } \\
\text { Income }\end{array}$ & $\begin{array}{l}9,791 \\
578.7\end{array}$ & $\begin{array}{c}2,447 \\
149\end{array}$ & $\begin{array}{c}88,119 \\
2,980\end{array}$ & $\begin{array}{c}23,510 \\
750.2\end{array}$ \\
\hline 2008 & $\begin{array}{l}\text { Total loans } \\
\text { Income }\end{array}$ & $\begin{array}{c}10,621 \\
745.9\end{array}$ & $\begin{array}{l}2,655 \\
133.7\end{array}$ & $\begin{array}{c}116,718 \\
3,340\end{array}$ & $\begin{array}{l}24,750 \\
1.081 .1\end{array}$ \\
\hline Year & $\begin{array}{l}\text { Inputs } \\
\text { Total deposits }\end{array}$ & Mean & Min & Max & SD \\
\hline 2003 & $\begin{array}{l}\text { Total deposits } \\
\text { Assets }\end{array}$ & $\begin{array}{l}11,518 \\
16,513\end{array}$ & $\begin{array}{l}2,337 \\
2,814\end{array}$ & $\begin{array}{l}69,108 \\
99,708\end{array}$ & $\begin{array}{l}19,750.3 \\
28,732.0\end{array}$ \\
\hline 2004 & $\begin{array}{c}\text { Total deposits } \\
\text { Assets }\end{array}$ & $\begin{array}{l}13,191 \\
18,098\end{array}$ & $\begin{array}{l}2,578 \\
3,415\end{array}$ & $\begin{array}{c}92,337 \\
108,588\end{array}$ & $\begin{array}{l}22,450.2 \\
32,765.1\end{array}$ \\
\hline 2005 & $\begin{array}{l}\text { Total deposits } \\
\text { Assets }\end{array}$ & $\begin{array}{l}14,847 \\
20,147\end{array}$ & $\begin{array}{l}2,820 \\
3,450\end{array}$ & $\begin{array}{l}103,929 \\
120,882\end{array}$ & $\begin{array}{c}25,412.45 \\
38,564.2\end{array}$ \\
\hline 2006 & $\begin{array}{l}\text { Total deposits } \\
\text { Assets }\end{array}$ & $\begin{array}{l}16,252 \\
21,759\end{array}$ & $\begin{array}{l}2,940 \\
3,615\end{array}$ & $\begin{array}{l}117,041 \\
130,554\end{array}$ & $\begin{array}{l}32,456.2 \\
42,453.3\end{array}$ \\
\hline 2007 & $\begin{array}{l}\text { Total deposits } \\
\text { Assets }\end{array}$ & $\begin{array}{l}18,570 \\
26,798\end{array}$ & $\begin{array}{l}3,068 \\
3,890\end{array}$ & $\begin{array}{l}148,560 \\
174,187\end{array}$ & $\begin{array}{l}41,780.1 \\
51,801.2\end{array}$ \\
\hline 2008 & $\begin{array}{l}\text { Total deposits } \\
\text { Assets }\end{array}$ & $\begin{array}{l}21,348 \\
30,952\end{array}$ & $\begin{array}{l}3,396 \\
4,850\end{array}$ & $\begin{array}{l}195,141 \\
216,664\end{array}$ & $\begin{array}{c}47,650.1 \\
66,789\end{array}$ \\
\hline
\end{tabular}

Table 3 shows that the overall efficiency of all banks increased prior to the global financial crisis with an overall average of 0.909. Egyptian banks can reduce the volume of their inputs by $10.1 \%$ and achieve the same results if the best manage-

Table 2. Input and output variables 
Table 3. Measures of efficiency of all banks before the crisis

\begin{tabular}{|c|c|c|c|c|c|}
\hline Year & Measures & Mean & Min & Max & SD \\
\hline 2003 & $\begin{array}{c}\text { Total efficiency: } \\
\text { Pure } \\
\text { Scale }\end{array}$ & $\begin{array}{l}0.871 \\
0.922 \\
0.945\end{array}$ & $\begin{array}{l}0.589 \\
0.621 \\
0.654\end{array}$ & $\begin{array}{l}1.00 \\
1.00 \\
1.00\end{array}$ & $\begin{array}{l}0.037 \\
0.014 \\
0.036\end{array}$ \\
\hline 2004 & $\begin{array}{c}\text { Total efficiency: } \\
\text { Pure } \\
\text { Scale }\end{array}$ & $\begin{array}{l}0.910 \\
0.949 \\
0.959\end{array}$ & $\begin{array}{l}0.524 \\
0.578 \\
0.624\end{array}$ & $\begin{array}{l}1.00 \\
1.00 \\
1.00\end{array}$ & $\begin{array}{l}0.174 \\
0.105 \\
0.092\end{array}$ \\
\hline 2005 & $\begin{array}{c}\text { Total efficiency: } \\
\text { Pure } \\
\text { Scale }\end{array}$ & $\begin{array}{l}0.896 \\
0.917 \\
0.978\end{array}$ & $\begin{array}{l}0.424 \\
0.498 \\
0.533\end{array}$ & $\begin{array}{l}1.00 \\
1.00 \\
1.00\end{array}$ & $\begin{array}{l}0.073 \\
0.020 \\
0.167\end{array}$ \\
\hline 2006 & $\begin{array}{c}\text { Total efficiency: } \\
\text { Pure } \\
\text { Scale }\end{array}$ & $\begin{array}{l}0.929 \\
0942 \\
0.987\end{array}$ & $\begin{array}{l}0.624 \\
0.698 \\
0.634\end{array}$ & $\begin{array}{l}1.00 \\
1.00 \\
1.00\end{array}$ & $\begin{array}{l}0.113 \\
0.134 \\
0.107\end{array}$ \\
\hline 2007 & $\begin{array}{c}\text { Total efficiency: } \\
\text { Pure } \\
\text { Scale }\end{array}$ & $\begin{array}{l}0.940 \\
0.957 \\
0.983\end{array}$ & $\begin{array}{l}0.785 \\
0.715 \\
0.689\end{array}$ & $\begin{array}{l}1.00 \\
1.00 \\
1.00\end{array}$ & $\begin{array}{l}0.156 \\
0.172 \\
0.143\end{array}$ \\
\hline 2008 & $\begin{array}{c}\text { Total efficiency: } \\
\text { Pure } \\
\text { Scale }\end{array}$ & $\begin{array}{l}0.908 \\
0.971 \\
0.936\end{array}$ & $\begin{array}{l}0.435 \\
0.412 \\
0.504\end{array}$ & $\begin{array}{l}1.00 \\
1.00 \\
1.00\end{array}$ & $\begin{array}{l}0.046 \\
0.124 \\
0.121\end{array}$ \\
\hline All years & $\begin{array}{l}\text { Total efficiency: } \\
\text { Pure } \\
\text { Scale }\end{array}$ & $\begin{array}{l}0.909 \\
0.970 \\
0.937\end{array}$ & $\begin{array}{l}0.563 \\
0.587 \\
0.606\end{array}$ & $\begin{array}{l}1.00 \\
1.00 \\
1.00\end{array}$ & $\begin{array}{l}0.099 \\
0.094 \\
0.111\end{array}$ \\
\hline
\end{tabular}

ment practices are adopted in banks, which will necessarily vary from one bank to another. Scale efficiency outperformed pure technical efficiency except for year 2008. Results conclude that Egyptian banks were incompetent in using their input resources.

Table 4 shows that the average technical efficiency of conventional commercial banks increased with an overall average of 0.893 . This result is consistent with the analysis of overall technical efficiency results of all Egyptian banks on the basis that conventional banks represent $71 \%$ of the study sample. Scaled efficiency outperformed pure efficiency except for year 2008. Egyptian banks are inefficient in using their input resources.

Table 5 shows that average technical efficiency of conventional banks with Islamic windows decreased with an overall average of 0.865 . This result is in line with the fact that the increase in the establishment of Islamic windows within the

Table 4. Measures of efficiency of conventional commercial banks before the crisis

\begin{tabular}{|c|c|c|c|c|c|}
\hline Year & Measures & Mean & Min & Max & SD \\
\hline 2003 & $\begin{array}{c}\text { Total efficiency: } \\
\text { Pure } \\
\text { Scale }\end{array}$ & $\begin{array}{l}0.826 \\
0.905 \\
0.913\end{array}$ & $\begin{array}{l}0.785 \\
0.781 \\
0.713\end{array}$ & $\begin{array}{l}1.00 \\
1.00 \\
1.00\end{array}$ & $\begin{array}{l}0.043 \\
0.021 \\
0.072\end{array}$ \\
\hline 2004 & $\begin{array}{l}\text { Total efficiency: } \\
\text { Pure } \\
\text { Scale }\end{array}$ & $\begin{array}{l}0.867 \\
0.921 \\
0.942\end{array}$ & $\begin{array}{l}0.878 \\
0.819 \\
0.789\end{array}$ & $\begin{array}{l}1.00 \\
1.00 \\
1.00\end{array}$ & $\begin{array}{l}0.031 \\
0.032 \\
0.041\end{array}$ \\
\hline 2005 & $\begin{array}{l}\text { Total efficiency: } \\
\text { Pure } \\
\text { Scale }\end{array}$ & $\begin{array}{l}0.930 \\
0.954 \\
0.975\end{array}$ & $\begin{array}{l}0.854 \\
0.930 \\
0.876\end{array}$ & $\begin{array}{l}1.00 \\
1.00 \\
1.00\end{array}$ & $\begin{array}{l}0.076 \\
0.242 \\
0.037\end{array}$ \\
\hline 2006 & $\begin{array}{l}\text { Total efficiency: } \\
\text { Pure } \\
\text { Scale }\end{array}$ & $\begin{array}{l}0.921 \\
0.941 \\
0.979\end{array}$ & $\begin{array}{l}0.825 \\
0.890 \\
0.852\end{array}$ & $\begin{array}{l}1.00 \\
1.00 \\
1.00\end{array}$ & $\begin{array}{l}0.036 \\
0.040 \\
0.051\end{array}$ \\
\hline 2007 & $\begin{array}{c}\text { Total efficiency: } \\
\text { Pure } \\
\text { Scale }\end{array}$ & $\begin{array}{l}0.974 \\
0.990 \\
0.983\end{array}$ & $\begin{array}{l}0.863 \\
0.872 \\
0.787\end{array}$ & $\begin{array}{l}1.00 \\
1.00 \\
1.00\end{array}$ & $\begin{array}{l}0.097 \\
0.045 \\
0.107\end{array}$ \\
\hline 2008 & $\begin{array}{c}\text { Total efficiency: } \\
\text { Pure } \\
\text { Scale }\end{array}$ & $\begin{array}{l}0.831 \\
0.913 \\
0.910\end{array}$ & $\begin{array}{l}0.785 \\
0.761 \\
0.763\end{array}$ & $\begin{array}{l}1.00 \\
1.00 \\
1.00\end{array}$ & $\begin{array}{l}0.103 \\
0.089 \\
0.121\end{array}$ \\
\hline All years & $\begin{array}{c}\text { Total efficiency: } \\
\text { Pure } \\
\text { Scale }\end{array}$ & $\begin{array}{l}0.893 \\
0.931 \\
0.959\end{array}$ & $\begin{array}{l}0.797 \\
0.842 \\
0.796\end{array}$ & $\begin{array}{l}1.00 \\
1.00 \\
1.00\end{array}$ & $\begin{array}{l}0.064 \\
0.078 \\
0.071\end{array}$ \\
\hline
\end{tabular}


Table 5. Measures of efficiency of conventional banks with Islamic windows before the crisis

\begin{tabular}{|c|c|c|c|c|c|}
\hline Year & Measures & Mean & Min & Max & SD \\
\hline 2003 & $\begin{array}{c}\text { Total efficiency: } \\
\text { Pure } \\
\text { Scale }\end{array}$ & $\begin{array}{l}0.800 \\
0.889 \\
0.900\end{array}$ & $\begin{array}{l}0.725 \\
0.743 \\
0.989\end{array}$ & $\begin{array}{l}1.00 \\
1.00 \\
1.00\end{array}$ & $\begin{array}{l}0.067 \\
0.015 \\
0.054\end{array}$ \\
\hline 2004 & $\begin{array}{c}\text { Total efficiency: } \\
\text { Pure } \\
\text { Scale }\end{array}$ & $\begin{array}{l}0.794 \\
0.880 \\
0.903\end{array}$ & $\begin{array}{l}0.761 \\
0.643 \\
0.853\end{array}$ & $\begin{array}{l}1.00 \\
1.00 \\
1.00\end{array}$ & $\begin{array}{l}0.197 \\
0.132 \\
0.321\end{array}$ \\
\hline 2005 & $\begin{array}{c}\text { Total efficiency: } \\
\text { Pure } \\
\text { Scale }\end{array}$ & $\begin{array}{l}0.794 \\
0.871 \\
0.912\end{array}$ & $\begin{array}{l}0.871 \\
0.781 \\
0.861\end{array}$ & $\begin{array}{l}1.00 \\
1.00 \\
1.00\end{array}$ & $\begin{array}{l}0.342 \\
0.114 \\
0.071\end{array}$ \\
\hline 2006 & $\begin{array}{c}\text { Total efficiency: } \\
\text { Pure } \\
\text { Scale }\end{array}$ & $\begin{array}{l}0.793 \\
0.860 \\
0.923\end{array}$ & $\begin{array}{l}0.873 \\
0.876 \\
0.789\end{array}$ & $\begin{array}{l}1.00 \\
1.00 \\
1.00\end{array}$ & $\begin{array}{l}0.087 \\
0.202 \\
0.155\end{array}$ \\
\hline 2007 & $\begin{array}{c}\text { Total efficiency: } \\
\text { Pure } \\
\text { Scale }\end{array}$ & $\begin{array}{l}0.757 \\
0.802 \\
0.945\end{array}$ & $\begin{array}{l}0.579 \\
0.643 \\
0.654\end{array}$ & $\begin{array}{l}1.00 \\
1.00 \\
1.00\end{array}$ & $\begin{array}{l}0.185 \\
0.194 \\
0.071\end{array}$ \\
\hline 2008 & $\begin{array}{c}\text { Total efficiency: } \\
\text { Pure } \\
\text { Scale }\end{array}$ & $\begin{array}{l}0.709 \\
0.803 \\
0.883\end{array}$ & $\begin{array}{l}0.521 \\
0.601 \\
0.540\end{array}$ & $\begin{array}{l}1.00 \\
1.00 \\
1.00\end{array}$ & $\begin{array}{l}0.305 \\
0.061 \\
0.196\end{array}$ \\
\hline All years & $\begin{array}{c}\text { Total efficiency: } \\
\text { Pure } \\
\text { Scale }\end{array}$ & $\begin{array}{l}0.865 \\
0.890 \\
0.971\end{array}$ & $\begin{array}{l}0.721 \\
0.714 \\
0.781\end{array}$ & $\begin{array}{l}1.00 \\
1.00 \\
1.00\end{array}$ & $\begin{array}{l}0.197 \\
0.119 \\
0.144\end{array}$ \\
\hline
\end{tabular}

conventional banking network has led to technical problems that have affected the overall efficiency of operating conventional banks with Islamic windows. The impact of the compatibility between the daily operating systems of conventional banks and the adoption of Islamic windows has affected the overall efficiency of banks. Scale efficiency outperformed pure technical efficiency referring to the misuse of the input resources. Although, conventional banks with Islamic windows operate at a reasonable scale.
Table 6 shows the average overall efficiency of Islamic banks increased with an overall average 0.870 . The overall efficiency of Islamic banks has improved compared to the case of conventional banks with Islamic windows but still is not as good compared to conventional banks. The number of Islamic banks operating in Egypt is still small and is increasing over time. Compared to results of conventional banks and conventional banks with Islamic windows, pure efficiency of Islamic banks outperformed scale efficiency. This

Table 6. Measures of efficiency of Islamic banks before the crisis

\begin{tabular}{|c|c|c|c|c|c|}
\hline Year & Measures & Mean & Min & Max & SD \\
\hline 2003 & $\begin{array}{c}\text { Total efficiency: } \\
\text { Pure } \\
\text { Scale }\end{array}$ & $\begin{array}{l}0.868 \\
0.952 \\
0.912\end{array}$ & $\begin{array}{l}0.521 \\
0.531 \\
0.540\end{array}$ & $\begin{array}{l}1.00 \\
1.00 \\
1.00\end{array}$ & $\begin{array}{l}0.231 \\
0.031 \\
0.310\end{array}$ \\
\hline 2004 & $\begin{array}{c}\text { Total efficiency: } \\
\text { Pure } \\
\text { Scale }\end{array}$ & $\begin{array}{l}0.846 \\
0.951 \\
0.890\end{array}$ & $\begin{array}{l}0.531 \\
0.520 \\
0.541\end{array}$ & $\begin{array}{l}1.00 \\
1.00 \\
1.00\end{array}$ & $\begin{array}{l}0.157 \\
0.158 \\
0.134\end{array}$ \\
\hline 2005 & $\begin{array}{c}\text { Total efficiency: } \\
\text { Pure } \\
\text { Scale }\end{array}$ & $\begin{array}{l}0.894 \\
0.963 \\
0.929\end{array}$ & $\begin{array}{l}0.489 \\
0.457 \\
0.431\end{array}$ & $\begin{array}{l}1.00 \\
1.00 \\
1.00\end{array}$ & $\begin{array}{l}0.077 \\
0.075 \\
0.002\end{array}$ \\
\hline 2006 & $\begin{array}{c}\text { Total efficiency: } \\
\text { Pure } \\
\text { Scale }\end{array}$ & $\begin{array}{l}0.877 \\
0.942 \\
0.931\end{array}$ & $\begin{array}{l}0.621 \\
0.501 \\
0.489\end{array}$ & $\begin{array}{l}1.00 \\
1.00 \\
1.00\end{array}$ & $\begin{array}{l}0.104 \\
0.105 \\
0.005\end{array}$ \\
\hline 2007 & $\begin{array}{c}\text { Total efficiency: } \\
\text { Pure } \\
\text { Scale }\end{array}$ & $\begin{array}{l}0.883 \\
0.971 \\
0.910\end{array}$ & $\begin{array}{l}0.560 \\
0.613 \\
0.789\end{array}$ & $\begin{array}{l}1.00 \\
1.00 \\
1.00\end{array}$ & $\begin{array}{l}0.075 \\
0.086 \\
0.045\end{array}$ \\
\hline 2008 & $\begin{array}{c}\text { Total efficiency: } \\
\text { Pure } \\
\text { Scale }\end{array}$ & $\begin{array}{l}0.853 \\
0.934 \\
0.914\end{array}$ & $\begin{array}{l}0.761 \\
0.640 \\
0.610\end{array}$ & $\begin{array}{l}1.00 \\
1.00 \\
1.00\end{array}$ & $\begin{array}{l}0.312 \\
0.213 \\
0.245\end{array}$ \\
\hline All years & $\begin{array}{c}\text { Total efficiency: } \\
\text { Pure } \\
\text { Scale }\end{array}$ & $\begin{array}{l}0.870 \\
0.952 \\
0.914\end{array}$ & $\begin{array}{l}0.580 \\
0.543 \\
0.567\end{array}$ & $\begin{array}{l}1.00 \\
1.00 \\
1.00\end{array}$ & $\begin{array}{l}0.159 \\
0.111 \\
0.123\end{array}$ \\
\hline
\end{tabular}


means that Islamic banks are efficient in both operation management and in using their input resources. One can attribute these results to the fact that Islamic banks operating in Egypt are subsidiaries of Islamic banks operating in the Gulf region for a long time. Accordingly, the Islamic banking departments have the necessary skills and expertise to market and offer their products and services efficiently.

\section{FINDINGS SUMMARY}

The minimum requirement of 12 decision making units for DEA analysis has been met. Since $n \geq\{m \cdot s, 3(m+s)\}$. Therefore, the number of variables selected in the analysis is reliable.
Conventional banks and conventional banks with Islamic windows are inefficient in using their resources compared to Islamic banks. Conventional banks account for $71 \%$ of the study sample and have the largest market share in Egypt. The opening of Islamic windows to introduce financial products according to Shari'ah complaint has a negative impact on the efficiency of conventional banks with Islamic windows as a result of reconciliation between the conventional system and Islamic system.

In terms of Islamic banks, results revealed that pure technical efficiency outperformed scale efficiency meaning that Islamic banks are efficient in using their input resources. Both pure and scale technical efficiency improved gradually. The market share of Islamic banks is increasing by the

Table 7. Input and output variables after the crisis

\begin{tabular}{|c|c|c|c|c|c|}
\hline Year & Outputs & Mean & Min & Max & SD \\
\hline 2009 & $\begin{array}{l}\text { Total loans } \\
\text { Income }\end{array}$ & $\begin{array}{l}9,734 \\
543.7\end{array}$ & $\begin{array}{c}2,433 \\
100\end{array}$ & $\begin{array}{c}55,871 \\
3,215\end{array}$ & $\begin{array}{c}16,315 \\
715\end{array}$ \\
\hline 2010 & $\begin{array}{l}\text { Total loans } \\
\text { Income }\end{array}$ & $\begin{array}{c}10,463 \\
583.8\end{array}$ & $\begin{array}{l}3,116 \\
130.7\end{array}$ & $\begin{array}{c}63,241 \\
3,778\end{array}$ & $\begin{array}{c}17,860 \\
815\end{array}$ \\
\hline 2011 & $\begin{array}{c}\text { Total loans } \\
\text { Income }\end{array}$ & $\begin{array}{c}11,806 \\
612.3\end{array}$ & $\begin{array}{l}3,902 \\
145.7\end{array}$ & $\begin{array}{c}77,458 \\
4,115\end{array}$ & $\begin{array}{c}21,625 \\
911\end{array}$ \\
\hline 2012 & $\begin{array}{l}\text { Total loans } \\
\text { Income }\end{array}$ & $\begin{array}{c}12,959 \\
745.9\end{array}$ & $\begin{array}{l}4,814 \\
188.9\end{array}$ & $\begin{array}{c}81,247 \\
4,952\end{array}$ & $\begin{array}{c}24,731 \\
1,234\end{array}$ \\
\hline 2013 & $\begin{array}{l}\text { Total loans } \\
\text { Income }\end{array}$ & $\begin{array}{c}14,750 \\
978.7\end{array}$ & $\begin{array}{c}5,847 \\
215\end{array}$ & $\begin{array}{c}93,129 \\
6,180\end{array}$ & $\begin{array}{r}26,210 \\
1,345\end{array}$ \\
\hline 2014 & $\begin{array}{l}\text { Total loans } \\
\text { Income }\end{array}$ & $\begin{array}{l}18,621 \\
10,231\end{array}$ & $\begin{array}{l}7,655 \\
311.7\end{array}$ & $\begin{array}{c}125,718 \\
6,940\end{array}$ & $\begin{array}{r}28,453 \\
1,453\end{array}$ \\
\hline 2015 & $\begin{array}{l}\text { Total loans } \\
\text { Income }\end{array}$ & $\begin{array}{l}20,126 \\
11,321\end{array}$ & $\begin{array}{l}9,108 \\
721.9\end{array}$ & $\begin{array}{c}139,813 \\
9,240\end{array}$ & $\begin{array}{c}31,401 \\
2,345\end{array}$ \\
\hline 2016 & $\begin{array}{l}\text { Total loans } \\
\text { Income }\end{array}$ & $\begin{array}{l}23,751 \\
13,791\end{array}$ & $\begin{array}{c}10,855 \\
982.7\end{array}$ & $\begin{array}{c}144,816 \\
10,490\end{array}$ & $\begin{array}{c}33,477 \\
3,217\end{array}$ \\
\hline 2017 & $\begin{array}{l}\text { Total loans } \\
\text { Income }\end{array}$ & $\begin{array}{l}25,856 \\
12,531\end{array}$ & $\begin{array}{l}12,557 \\
1021.7\end{array}$ & $\begin{array}{c}150,674 \\
11,640\end{array}$ & $\begin{array}{c}35,483 \\
4,453\end{array}$ \\
\hline Year & Inputs & Mean & Min & Max & SD \\
\hline 2009 & $\begin{array}{c}\text { Total deposits } \\
\text { Assets }\end{array}$ & $\begin{array}{l}13,218 \\
18,113\end{array}$ & $\begin{array}{l}3,430 \\
4,914\end{array}$ & $\begin{array}{c}70,100 \\
101,008\end{array}$ & $\begin{array}{l}21,850 \\
30,232\end{array}$ \\
\hline 2010 & $\begin{array}{c}\text { Total deposits } \\
\text { Assets }\end{array}$ & $\begin{array}{l}15,190 \\
19,298\end{array}$ & $\begin{array}{l}4,878 \\
6,115\end{array}$ & $\begin{array}{c}94,237 \\
110,508\end{array}$ & $\begin{array}{l}23,750 \\
35,865\end{array}$ \\
\hline 2011 & $\begin{array}{c}\text { Total deposits } \\
\text { Assets }\end{array}$ & $\begin{array}{l}16,147 \\
22,947\end{array}$ & $\begin{array}{l}5,820 \\
7,350\end{array}$ & $\begin{array}{l}105,900 \\
125,880\end{array}$ & $\begin{array}{l}28,710 \\
41,804\end{array}$ \\
\hline 2012 & $\begin{array}{c}\text { Total deposits } \\
\text { Assets }\end{array}$ & $\begin{array}{l}18,452 \\
25,859\end{array}$ & $\begin{array}{l}6,740 \\
7,815\end{array}$ & $\begin{array}{l}117,341 \\
135,524\end{array}$ & $\begin{array}{l}35,550 \\
47,653\end{array}$ \\
\hline 2013 & $\begin{array}{c}\text { Total deposits } \\
\text { Assets }\end{array}$ & $\begin{array}{l}20,578 \\
27,198\end{array}$ & $\begin{array}{c}8,268 \\
10,800\end{array}$ & $\begin{array}{l}158,500 \\
184,187\end{array}$ & $\begin{array}{l}46,700 \\
55,401\end{array}$ \\
\hline 2014 & $\begin{array}{c}\text { Total deposits } \\
\text { Assets }\end{array}$ & $\begin{array}{l}24,548 \\
32,652\end{array}$ & $\begin{array}{l}10,306 \\
13,950\end{array}$ & $\begin{array}{l}199,101 \\
220,694\end{array}$ & $\begin{array}{l}51,650 \\
70,906\end{array}$ \\
\hline 2015 & $\begin{array}{c}\text { Total deposits } \\
\text { Assets }\end{array}$ & $\begin{array}{l}27,645 \\
34,256\end{array}$ & $\begin{array}{l}13,603 \\
14,051\end{array}$ & $\begin{array}{l}215,171 \\
228,946\end{array}$ & $\begin{array}{l}58,691 \\
75,205\end{array}$ \\
\hline 2016 & $\begin{array}{c}\text { Total deposits } \\
\text { Assets }\end{array}$ & $\begin{array}{l}29,845 \\
36,152\end{array}$ & $\begin{array}{l}15,456 \\
16,923\end{array}$ & $\begin{array}{l}220,187 \\
227,163\end{array}$ & $\begin{array}{l}65,693 \\
78,209\end{array}$ \\
\hline 2017 & $\begin{array}{c}\text { Total deposits } \\
\text { Assets }\end{array}$ & $\begin{array}{l}30,108 \\
40,212\end{array}$ & $\begin{array}{l}17,256 \\
18,509\end{array}$ & $\begin{array}{l}230,709 \\
239,492\end{array}$ & $\begin{array}{l}78,850 \\
84,926\end{array}$ \\
\hline
\end{tabular}


time. Therefore, it is found that the efficiency of the Islamic banks' operation increased during the study period. This is because Islamic banks operating in Egypt are branches of some banks that operate in the Gulf region for a long time.

\section{EFFICIENCY MEASURES AFTER THE FINANCIAL CRISIS}

Table 8 shows that as a result of the global financial crisis, the relative efficiency of most Egyptian banks has decreased due to the negative impact on the international financial portfolios of these banks with an overall efficiency of 0.730 . Scale efficiency still outperformed pure technical efficiency but with a lower rate compared to the same results before the financial crisis. This means that Egyptian banks are still inefficient in using the input resources.

Table 9 shows that efficiency of conventional banks has decreased since it represents almost $71 \%$ of the study sample due to the negative impact on the international financial portfolios of these banks due to the crisis with an overall efficiency of 0.771 . Scale efficiency outperformed pure technical efficiency but at a lower rate compared to the period from 2003 to 2008 before the financial crisis.

Table 10 indicates that results of the efficiency analysis of conventional banks with Islamic windows have a gradual decrease and then are relatively stable thereafter due to the international financial crisis with an average of 0.795 . This can be attributed to the dual effect of the financial crisis and the presence of financial investment of these banks in the international financial markets, the integration of Islamic banking operations within the conventional banking operations and the negative impact of this integration on efficiency. Scale efficiency outperformed pure efficiency except for year 2011, the year of January revolution which had a negative impact on the operations of all Egyptian banks. Scale efficiency outperformed pure efficiency but at a lower rate compared to the same results before financial crisis.

Table 8. Measures of efficiency of all banks after the crisis

\begin{tabular}{|c|c|c|c|c|c|}
\hline Year & Measures & Mean & Min & Max & SD \\
\hline 2009 & $\begin{array}{c}\text { Total efficiency: } \\
\text { Pure } \\
\text { Scale }\end{array}$ & $\begin{array}{l}0.716 \\
0.884 \\
0.810\end{array}$ & $\begin{array}{l}0.431 \\
0.356 \\
0.521\end{array}$ & $\begin{array}{l}1.00 \\
1.00 \\
1.00\end{array}$ & $\begin{array}{l}0.103 \\
0.093 \\
0.110\end{array}$ \\
\hline 2010 & $\begin{array}{c}\text { Total efficiency: } \\
\text { Pure } \\
\text { Scale }\end{array}$ & $\begin{array}{l}0.601 \\
0.785 \\
0.765\end{array}$ & $\begin{array}{l}0.440 \\
0.395 \\
0.421\end{array}$ & $\begin{array}{l}1.00 \\
1.00 \\
1.00\end{array}$ & $\begin{array}{l}0.105 \\
0.110 \\
0.109\end{array}$ \\
\hline 2011 & $\begin{array}{c}\text { Total efficiency: } \\
\text { Pure } \\
\text { Scale }\end{array}$ & $\begin{array}{l}0.720 \\
0.834 \\
0.863\end{array}$ & $\begin{array}{l}0.372 \\
0.515 \\
0.523\end{array}$ & $\begin{array}{l}1.00 \\
1.00 \\
1.00\end{array}$ & $\begin{array}{l}0.102 \\
0.054 \\
0.072\end{array}$ \\
\hline 2012 & $\begin{array}{c}\text { Total efficiency: } \\
\text { Pure } \\
\text { Scale }\end{array}$ & $\begin{array}{l}0.790 \\
0.892 \\
0.886\end{array}$ & $\begin{array}{l}0.511 \\
0.491 \\
0.623\end{array}$ & $\begin{array}{l}1.00 \\
1.00 \\
1.00\end{array}$ & $\begin{array}{l}0.032 \\
0.021 \\
0.124\end{array}$ \\
\hline 2013 & $\begin{array}{c}\text { Total efficiency: } \\
\text { Pure } \\
\text { Scale }\end{array}$ & $\begin{array}{l}0.765 \\
0.870 \\
0.879\end{array}$ & $\begin{array}{l}0.210 \\
0.231 \\
0.510\end{array}$ & $\begin{array}{l}1.00 \\
1.00 \\
1.00\end{array}$ & $\begin{array}{l}0.201 \\
0.210 \\
0.141\end{array}$ \\
\hline 2014 & $\begin{array}{c}\text { Total efficiency: } \\
\text { Pure } \\
\text { Scale }\end{array}$ & $\begin{array}{l}0.790 \\
0.883 \\
0.895\end{array}$ & $\begin{array}{l}0.340 \\
0.221 \\
0.325\end{array}$ & $\begin{array}{l}1.00 \\
1.00 \\
1.00\end{array}$ & $\begin{array}{l}0.131 \\
0.171 \\
0.105\end{array}$ \\
\hline 2015 & $\begin{array}{c}\text { Total efficiency: } \\
\text { Pure } \\
\text { Scale }\end{array}$ & $\begin{array}{l}0.780 \\
0.882 \\
0.884\end{array}$ & $\begin{array}{l}0.344 \\
0.261 \\
0.325\end{array}$ & $\begin{array}{l}1.00 \\
1.00 \\
1.00\end{array}$ & $\begin{array}{l}0.121 \\
0.151 \\
0.143\end{array}$ \\
\hline 2016 & $\begin{array}{c}\text { Total efficiency: } \\
\text { Pure } \\
\text { Scale }\end{array}$ & $\begin{array}{l}0.798 \\
0.870 \\
0.917\end{array}$ & $\begin{array}{l}0.323 \\
0.231 \\
0.352\end{array}$ & $\begin{array}{l}1.00 \\
1.00 \\
1.00\end{array}$ & $\begin{array}{l}0.121 \\
0.131 \\
0.125\end{array}$ \\
\hline 2017 & $\begin{array}{c}\text { Total efficiency: } \\
\text { Pure } \\
\text { Scale }\end{array}$ & $\begin{array}{l}0.793 \\
0.810 \\
0.979\end{array}$ & $\begin{array}{l}0.339 \\
0.211 \\
0.355\end{array}$ & $\begin{array}{l}1.00 \\
1.00 \\
1.00\end{array}$ & $\begin{array}{l}0.141 \\
0.191 \\
0.115\end{array}$ \\
\hline All years & $\begin{array}{l}\text { Total efficiency: } \\
\text { Pure } \\
\text { Scale }\end{array}$ & $\begin{array}{l}0.730 \\
0.858 \\
0.850\end{array}$ & $\begin{array}{l}0.384 \\
0.368 \\
0.487\end{array}$ & $\begin{array}{l}1.00 \\
1.00 \\
1.00\end{array}$ & $\begin{array}{l}0.132 \\
0.109 \\
0.110\end{array}$ \\
\hline
\end{tabular}


Table 9. Measures of efficiency of conventional banks after the crisis

\begin{tabular}{|c|c|c|c|c|c|}
\hline Year & Measures & Mean & Min & Max & SD \\
\hline 2009 & $\begin{array}{c}\text { Total efficiency: } \\
\text { Pure } \\
\text { Scale }\end{array}$ & $\begin{array}{l}0.647 \\
0.790 \\
0.819\end{array}$ & $\begin{array}{l}0.442 \\
0.379 \\
0.531\end{array}$ & $\begin{array}{l}1.00 \\
1.00 \\
1.00\end{array}$ & $\begin{array}{l}0.110 \\
0.142 \\
0.132\end{array}$ \\
\hline 2010 & $\begin{array}{c}\text { Total efficiency: } \\
\text { Pure } \\
\text { Scale }\end{array}$ & $\begin{array}{l}0.741 \\
0.841 \\
0.882\end{array}$ & $\begin{array}{l}0.330 \\
0.432 \\
0.520\end{array}$ & $\begin{array}{l}1.00 \\
1.00 \\
1.00\end{array}$ & $\begin{array}{l}0.231 \\
0.234 \\
0.219\end{array}$ \\
\hline 2011 & $\begin{array}{c}\text { Total efficiency: } \\
\text { Pure } \\
\text { Scale }\end{array}$ & $\begin{array}{l}0.766 \\
0.880 \\
0.870\end{array}$ & $\begin{array}{l}0.501 \\
0.414 \\
0.671\end{array}$ & $\begin{array}{l}1.00 \\
1.00 \\
1.00\end{array}$ & $\begin{array}{l}0.223 \\
0.321 \\
0.202\end{array}$ \\
\hline 2012 & $\begin{array}{c}\text { Total efficiency: } \\
\text { Pure } \\
\text { Scale }\end{array}$ & $\begin{array}{l}0.800 \\
0.887 \\
0.901\end{array}$ & $\begin{array}{l}0.421 \\
0.342 \\
0.440\end{array}$ & $\begin{array}{l}1.00 \\
1.00 \\
1.00\end{array}$ & $\begin{array}{l}0.109 \\
0.121 \\
0.121\end{array}$ \\
\hline 2013 & $\begin{array}{c}\text { Total efficiency: } \\
\text { Pure } \\
\text { Scale }\end{array}$ & $\begin{array}{l}0.866 \\
0.920 \\
0.942\end{array}$ & $\begin{array}{l}0.512 \\
0.441 \\
0.451\end{array}$ & $\begin{array}{l}1.00 \\
1.00 \\
1.00\end{array}$ & $\begin{array}{l}0.122 \\
0.124 \\
0.138\end{array}$ \\
\hline 2014 & $\begin{array}{c}\text { Total efficiency: } \\
\text { Pure } \\
\text { Scale }\end{array}$ & $\begin{array}{l}0.808 \\
0.823 \\
0.982\end{array}$ & $\begin{array}{l}0.529 \\
0.492 \\
0.541\end{array}$ & $\begin{array}{l}1.00 \\
1.00 \\
1.00\end{array}$ & $\begin{array}{l}0.134 \\
0.210 \\
0.289\end{array}$ \\
\hline 2015 & $\begin{array}{c}\text { Total efficiency: } \\
\text { Pure } \\
\text { Scale }\end{array}$ & $\begin{array}{l}0.826 \\
0.849 \\
0.972\end{array}$ & $\begin{array}{l}0.540 \\
0.444 \\
0.537\end{array}$ & $\begin{array}{l}1.00 \\
1.00 \\
1.00\end{array}$ & $\begin{array}{l}0.130 \\
0.219 \\
0.249\end{array}$ \\
\hline 2016 & $\begin{array}{c}\text { Total efficiency: } \\
\text { Pure } \\
\text { Scale }\end{array}$ & $\begin{array}{l}0.825 \\
0.843 \\
0.978\end{array}$ & $\begin{array}{l}0.537 \\
0.406 \\
0.523\end{array}$ & $\begin{array}{l}1.00 \\
1.00 \\
1.00\end{array}$ & $\begin{array}{l}0.136 \\
0.230 \\
0.298\end{array}$ \\
\hline 2017 & $\begin{array}{c}\text { Total efficiency: } \\
\text { Pure } \\
\text { Scale }\end{array}$ & $\begin{array}{l}0.845 \\
0.847 \\
0.997\end{array}$ & $\begin{array}{l}0.540 \\
0.482 \\
0.561\end{array}$ & $\begin{array}{l}1.00 \\
1.00 \\
1.00\end{array}$ & $\begin{array}{l}0.174 \\
0.243 \\
0.249\end{array}$ \\
\hline All years & $\begin{array}{c}\text { Total efficiency: } \\
\text { Pure } \\
\text { Scale }\end{array}$ & $\begin{array}{l}0.771 \\
0.856 \\
0.900 \\
\end{array}$ & $\begin{array}{l}0.455 \\
0.417 \\
0.525 \\
\end{array}$ & $\begin{array}{l}1.00 \\
1.00 \\
1.00\end{array}$ & $\begin{array}{l}0.154 \\
0.192 \\
0.183 \\
\end{array}$ \\
\hline
\end{tabular}

Table 10. Measures of efficiency of conventional banks with Islamic windows after the crisis

\begin{tabular}{|c|c|c|c|c|c|}
\hline Year & Measures & Mean & Min & Max & SD \\
\hline 2009 & $\begin{array}{c}\text { Total efficiency: } \\
\text { Pure } \\
\text { Scale }\end{array}$ & $\begin{array}{l}0.810 \\
0.897 \\
0.903\end{array}$ & $\begin{array}{l}0.621 \\
0.530 \\
0.528\end{array}$ & $\begin{array}{l}1.00 \\
1.00 \\
1.00\end{array}$ & $\begin{array}{l}0.102 \\
0.191 \\
0.014\end{array}$ \\
\hline 2010 & $\begin{array}{c}\text { Total efficiency: } \\
\text { Pure } \\
\text { Scale }\end{array}$ & $\begin{array}{l}0.758 \\
0.879 \\
0.862\end{array}$ & $\begin{array}{l}0.341 \\
0.452 \\
0.411\end{array}$ & $\begin{array}{l}1.00 \\
1.00 \\
1.00\end{array}$ & $\begin{array}{l}0.220 \\
0.314 \\
0.301\end{array}$ \\
\hline 2011 & $\begin{array}{c}\text { Total efficiency: } \\
\text { Pure } \\
\text { Scale }\end{array}$ & $\begin{array}{l}0.812 \\
0.893 \\
0.909\end{array}$ & $\begin{array}{l}0.344 \\
0.389 \\
0.492\end{array}$ & $\begin{array}{l}1.00 \\
1.00 \\
1.00\end{array}$ & $\begin{array}{l}0.304 \\
0.245 \\
0.317\end{array}$ \\
\hline 2012 & $\begin{array}{c}\text { Total efficiency: } \\
\text { Pure } \\
\text { Scale }\end{array}$ & $\begin{array}{l}0.772 \\
0.813 \\
0.949\end{array}$ & $\begin{array}{l}0.412 \\
0.520 \\
0.254\end{array}$ & $\begin{array}{l}1.00 \\
1.00 \\
1.00\end{array}$ & $\begin{array}{l}0.201 \\
0.130 \\
0.201\end{array}$ \\
\hline 2013 & $\begin{array}{c}\text { Total efficiency: } \\
\text { Pure } \\
\text { Scale }\end{array}$ & $\begin{array}{l}0.812 \\
0.874 \\
0.929\end{array}$ & $\begin{array}{l}0.280 \\
0.354 \\
0.231\end{array}$ & $\begin{array}{l}1.00 \\
1.00 \\
1.00\end{array}$ & $\begin{array}{l}0.103 \\
0.133 \\
0.399\end{array}$ \\
\hline 2014 & $\begin{array}{c}\text { Total efficiency: } \\
\text { Pure } \\
\text { Scale }\end{array}$ & $\begin{array}{l}0.806 \\
0.884 \\
0.911\end{array}$ & $\begin{array}{l}0.400 \\
0.429 \\
0.524\end{array}$ & $\begin{array}{l}1.00 \\
1.00 \\
1.00\end{array}$ & $\begin{array}{l}0.423 \\
0.245 \\
0.452\end{array}$ \\
\hline 2015 & $\begin{array}{c}\text { Total efficiency: } \\
\text { Pure } \\
\text { Scale }\end{array}$ & $\begin{array}{l}0.846 \\
0.873 \\
0.969\end{array}$ & $\begin{array}{l}0.441 \\
0.459 \\
0.564\end{array}$ & $\begin{array}{l}1.00 \\
1.00 \\
1.00\end{array}$ & $\begin{array}{l}0.443 \\
0.315 \\
0.402\end{array}$ \\
\hline 2016 & $\begin{array}{c}\text { Total efficiency: } \\
\text { Pure } \\
\text { Scale }\end{array}$ & $\begin{array}{l}0.876 \\
0.894 \\
0.979\end{array}$ & $\begin{array}{l}0.474 \\
0.430 \\
0.519\end{array}$ & $\begin{array}{l}1.00 \\
1.00 \\
1.00\end{array}$ & $\begin{array}{l}0.445 \\
0.425 \\
0.462\end{array}$ \\
\hline 2017 & $\begin{array}{c}\text { Total efficiency: } \\
\text { Pure } \\
\text { Scale }\end{array}$ & $\begin{array}{l}0.796 \\
0.864 \\
0.921\end{array}$ & $\begin{array}{l}0.395 \\
0.419 \\
0.504\end{array}$ & $\begin{array}{l}1.00 \\
1.00 \\
1.00\end{array}$ & $\begin{array}{l}0.398 \\
0.275 \\
0.425\end{array}$ \\
\hline All years & $\begin{array}{c}\text { Total efficiency: } \\
\text { Pure } \\
\text { Scale }\end{array}$ & $\begin{array}{l}0.795 \\
0.873 \\
0.910 \\
\end{array}$ & $\begin{array}{l}0.399 \\
0.445 \\
0.406 \\
\end{array}$ & $\begin{array}{l}1.00 \\
1.00 \\
1.00 \\
\end{array}$ & $\begin{array}{l}0.225 \\
0.209 \\
0.280 \\
\end{array}$ \\
\hline
\end{tabular}


Table 11. Measures of efficiency of Islamic banks after the crisis

\begin{tabular}{|c|c|c|c|c|c|}
\hline Year & Measures & Mean & Min & Max & SD \\
\hline 2009 & $\begin{array}{c}\text { Total efficiency: } \\
\text { Pure } \\
\text { Scale }\end{array}$ & $\begin{array}{l}0.782 \\
0.894 \\
0.875\end{array}$ & $\begin{array}{l}0.452 \\
0.461 \\
0.505\end{array}$ & $\begin{array}{l}1.00 \\
1.00 \\
1.00\end{array}$ & $\begin{array}{l}0.301 \\
0.241 \\
0.200\end{array}$ \\
\hline 2010 & $\begin{array}{c}\text { Total efficiency: } \\
\text { Pure } \\
\text { Scale }\end{array}$ & $\begin{array}{l}0.930 \\
0.985 \\
0.945\end{array}$ & $\begin{array}{l}0.354 \\
0.345 \\
0.214\end{array}$ & $\begin{array}{l}1.00 \\
1.00 \\
1.00\end{array}$ & $\begin{array}{l}0.321 \\
0.231 \\
0.241\end{array}$ \\
\hline 2011 & $\begin{array}{c}\text { Total efficiency: } \\
\text { Pure } \\
\text { Scale }\end{array}$ & $\begin{array}{l}0.917 \\
0.973 \\
0.943\end{array}$ & $\begin{array}{l}0.411 \\
0.394 \\
0.321\end{array}$ & $\begin{array}{l}1.00 \\
1.00 \\
1.00\end{array}$ & $\begin{array}{l}0.234 \\
0.251 \\
0.261\end{array}$ \\
\hline 2012 & $\begin{array}{c}\text { Total efficiency: } \\
\text { Pure } \\
\text { Scale }\end{array}$ & $\begin{array}{l}0.941 \\
0.982 \\
0.959\end{array}$ & $\begin{array}{l}0.523 \\
0.552 \\
0.546\end{array}$ & $\begin{array}{l}1.00 \\
1.00 \\
1.00\end{array}$ & $\begin{array}{l}0.332 \\
0.345 \\
0.242\end{array}$ \\
\hline 2013 & $\begin{array}{c}\text { Total efficiency: } \\
\text { Pure } \\
\text { Scale }\end{array}$ & $\begin{array}{l}0.902 \\
0.990 \\
0.912\end{array}$ & $\begin{array}{l}0.349 \\
0.562 \\
0.621\end{array}$ & $\begin{array}{l}1.00 \\
1.00 \\
1.00\end{array}$ & $\begin{array}{l}0.231 \\
0.331 \\
0.345\end{array}$ \\
\hline 2014 & $\begin{array}{c}\text { Total efficiency: } \\
\text { Pure } \\
\text { Scale }\end{array}$ & $\begin{array}{l}0.861 \\
0.945 \\
0.911\end{array}$ & $\begin{array}{l}0.632 \\
0.645 \\
0.540\end{array}$ & $\begin{array}{l}1.00 \\
1.00 \\
1.00\end{array}$ & $\begin{array}{l}0.245 \\
0.341 \\
0.245\end{array}$ \\
\hline 2015 & $\begin{array}{c}\text { Total efficiency: } \\
\text { Pure } \\
\text { Scale }\end{array}$ & $\begin{array}{l}0.881 \\
0.907 \\
0.971\end{array}$ & $\begin{array}{l}0.645 \\
0.685 \\
0.567\end{array}$ & $\begin{array}{l}1.00 \\
1.00 \\
1.00\end{array}$ & $\begin{array}{l}0.246 \\
0.321 \\
0.275\end{array}$ \\
\hline 2016 & $\begin{array}{c}\text { Total efficiency: } \\
\text { Pure } \\
\text { Scale }\end{array}$ & $\begin{array}{l}0.847 \\
0.915 \\
0.925\end{array}$ & $\begin{array}{l}0.672 \\
0.622 \\
0.540\end{array}$ & $\begin{array}{l}1.00 \\
1.00 \\
1.00\end{array}$ & $\begin{array}{l}0.291 \\
0.311 \\
0.205\end{array}$ \\
\hline 2017 & $\begin{array}{c}\text { Total efficiency: } \\
\text { Pure } \\
\text { Scale }\end{array}$ & $\begin{array}{l}0.842 \\
0.911 \\
0.925\end{array}$ & $\begin{array}{l}0.690 \\
0.684 \\
0.560\end{array}$ & $\begin{array}{l}1.00 \\
1.00 \\
1.00\end{array}$ & $\begin{array}{l}0.235 \\
0.301 \\
0.233\end{array}$ \\
\hline All years & $\begin{array}{l}\text { Total efficiency: } \\
\text { Pure } \\
\text { Scale }\end{array}$ & $\begin{array}{l}0.886 \\
0.961 \\
0.922 \\
\end{array}$ & $\begin{array}{l}0.452 \\
0.493 \\
0.457\end{array}$ & $\begin{array}{l}1.00 \\
1.00 \\
1.00\end{array}$ & $\begin{array}{l}0.267 \\
0.298 \\
0.245\end{array}$ \\
\hline
\end{tabular}

Table 12. Summary of conclusions

\begin{tabular}{l|c|c}
\hline Category of banks & Before crisis & After crisis \\
\hline All banks & 0.909 & 0.730 \\
Conventional banks & 0.893 & 0.775 \\
Conventional banks with Islamic windows & 0.870 & 0.771 \\
\hline Islamic banks & 0.795 \\
\hline
\end{tabular}

Table 11 indicates that results of Islamic banks improved with a mean efficiency ratio of 0.821 meaning that Islamic banks could use only 0.886 of the inputs to achieve the outputs. The market share of Islamic banks in Egypt is lower than conventional banks. It was at the stage of growth after the January revolution and the Muslim Brotherhood was leading the political scene. After the revolution of June, the growth of Islamic banking activities was limited compared to conventional banks. Egypt is one of the Arab countries attracting the activity of Islamic banks, supported by steady annual growth in population and Islamic culture of Egyptian people. The removal of the Muslim Brotherhood's rule has negatively affected the growth of Islamic banks. These results can be for two reasons. Islamic banks operating in Egypt represent branches of some foreign banks that have been operating in the Gulf region for a long time and have the necessary expertise and technical skills. Secondly, the market share of Islamic banks is increasing.

\section{CONCLUSION}

This is a novel research to examine the efficiency of banks operating in Egypt. Before the global financial crisis, the results confirmed the superiority of conventional banks compared to Islamic and conventional banks with Islamic windows. The superiority of conventional banks stems from the level of experi- 
ence for stuff and the increase in the market share. Scale efficiency outperformed pure efficiency. The efficiency of conventional banks has gradually decreased compared to conventional banks with Islamic windows to reach 0.775 and Islamic banks to reach 0.870 . Low technical efficiency of conventional banks with Islamic windows is due to the adoption of the Islamic windows in several branches of these banks and the impact of technical issues on the efficiency of these banks.

Technical efficiency of Islamic banks has improved compared to conventional banks to reach 0.870 . These results confirm that pure technical efficiency has exceeded the efficiency of scale, which means that Islamic banks are more efficient in management and in using their input resources. After the financial crisis, technical efficiency of all banks decreased to reach 0.730 , it is 0.771 for conventional banks, 0.795 for conventional banks with Islamic windows and 0.886 for Islamic banks. This shows the improvement of efficiency of Islamic banks after the crisis due to the efficient management. Islamic banks can play important role in financial inclusion, boosting the economy and integrating the informal economy.

\section{REFERENCES}

1. Abdul-Majid, M., Saal, S. D., \& Battisti, G. (2009). Efficiency in Islamic and conventional banking: an international comparison. Journal of Production Analysis, 34(1), 25-43.

2. Abdul-Wahab, A.-H., \& Haron, R. (2017). Efficiency of Qatari banking industry: an empirical investigation. International Journal of Bank Marketing, 35(2), 298-318. http://doi.org/10.1108/IJBM-072016-0090

3. Ahmed, S., \& Abdul Rahman, A. (2012). The efficiency of Islamic and Conventional commercial banks in Malaysia. International Journal of Islamic and Middle Eastern Finance and Management, 5(3), 241-263. https://doi. org/10.1108/17538391211255223

4. Benston, G. J. (1965). Branch banking and economies of scale. Journal of Finance, 20(2), 312-331. Retrieved from https://econpapers. repec.org/article/blajfinan/v_3a2 0_3ay_3a1965_3ai_3a2_3ap_ 3a312-331.htm

5. Berger, A. N., \& Humphrey, D. B. (1997). Efficiency of financial institutions: international survey and directions for future research. European Journal of Operational Research, 98(2), 175-212. https://doi.org/10.1016/S03772217(96)00342-6

6. Coelli, T. (1996). A guide to DEAP version 2.1: A data envelopment analysis (computer) program (CEPA Working Paper 96/08). Armidale: University of New England. Retrieved from http://www.owlnet. rice.edu/ econ380/DEAP.PDF

7. Farrell, M. J. (1957). The measurement of productive efficiency. Journal of Royal Statistical Society, 120(3), 253-290. https://doi.org/10.2307/2343100

8. Gishkori, M. A., \& Ullah, N. (2013). Technical efficiency of Islamic and commercial banks evidence from Pakistan using DEA Model (2007-2011). Journal of Business and Management, 7(4), 68-76. Retrieved from http://iosrjournals. org/iosr-jbm/papers/Vol7-issue4/ I0746876.pdf

9. Hardianto, D. S., \& Wulandari, P. (2016). Islamic bank versus conventional bank: intermediation fee-based service activity and efficiency. International Journal of Islamic and Middle Eastern Finance and Management, 9(2), 296-311. https://doi.org/10.1108/ IMEFM-01-2015-0003

10. Kamarudin, F., Nordin, B. A. A., Muhammad, J., \& Hamid, M. A. A. (2014a). Cost, revenue and profit efficiency of Islamic and conventional banking sector; empirical evidence from Gulf cooperative council countries. Global Business Review, 15(1), 1-24. https://doi. org/10.1177/0972150913515579
11. Louati, S., \& Boujelbene, Y. (2015). Banks' stability-efficiency within dual banking system: a stochastic frontier analysis. International Journal of Islamic and Middle Eastern Finance and Management, 8(4), 472-490. https://doi. org/10.1108/IMEFM-12-2014-0121

12. Miah, D. M., \& Sharmeen, K. (2015). Relationship between capital risk and efficiency: A comparative study between Islamic and conventional banks of Bangladesh. International Journal of Islamic and Middle Eastern Finance and Management, 8(2), 203-221. http://dx.doi.org/10.1108/ IMEFM-03-2014-0027

13. Sealey, C., \& Lindley, J. T. (1977). Inputs, outputs and a theory of Production and cost at depository financial institutions. Journal of Finance, 32(4), 1251-1266.

14. Srairi, S. A (2010). Cost and profit efficiency of conventional and Islamic banks in GCC countries. Journal of Productivity Analysis, 34(1), 45-62. http://dx.doi. org/10.1007/s11123-009-0161-7

15. Sufian, F., Kamarudin, F., \& Noor, M. H. H. N. (2013). Assessing the revenue efficiency of domestic and foreign Islamic banks: empirical evidence from Malaysia. Journal Pengurusan, 37(1), 77-90. Retrieved from http://journalarticle.ukm.my/6960/1/3629-80901-PB.pdf 
16. Trabelsi, M. A., \& Trad, N. (2017). Profitability and risk in interest-free banking industries: a dynamic panel data analysis. International Journal of Islamic and Middle Eastern Finance and Management, 10(4), 454-469. https://doi.org/10.1108/IMEFM-05-2016-0070
17. Yehya, M., Muhammad, J., \& Hadi, A. R. A. (2012). A comparative study on the level of efficiency between Islamic and conventional banking systems in Malaysia. International Journal of Islamic and Middle Eastern Finance and Management, 5(1), 48-62. https://doi. org/10.1108/17538391211216820
18. Yudistira, D. (2004). Efficiency in Islamic banking: an empirical analysis of eighteen banks. Islamic Economic Studies, 12(1), 2-9. Retrieved from http://www.irti. org/English/Research/Documents/ IES/095.pdf

\section{APPENDIX A}

\section{Table A1. The sample}

\begin{tabular}{|c|c|c|}
\hline No. & Name of a bank & Type of a bank \\
\hline 1 & Commercial International Bank & $\mathrm{CCB}$ \\
\hline 2 & Union National Bank - Egypt & CCB \\
\hline 3 & Société Arabe International De Banque (SAIB) & $\mathrm{CCB}$ \\
\hline 4 & Suez Canal Bank & $\mathrm{CCB}$ \\
\hline 5 & Arab African International Bank & $\mathrm{CCB}$ \\
\hline 6 & Principal Bank for Development and Agricultural Credit & $\mathrm{CCB}$ \\
\hline 7 & Arab International Bank & CCB \\
\hline 8 & Export Development Bank of Egypt & $\mathrm{CCB}$ \\
\hline 9 & The National Bank of Kuwait Egypt & CCB \\
\hline 10 & United Bank & CCB \\
\hline 11 & Al Ahli United Bank & $\mathrm{CCB}$ \\
\hline 12 & Housing and Development Bank & $\mathrm{CCB}$ \\
\hline 13 & Industrial Development and Workers Bank & CCB \\
\hline 14 & Arab Investment Bank & CCB \\
\hline 15 & Arab Bank Corporation & CCB \\
\hline 16 & Bank Audi & CCB \\
\hline 17 & Bloom Bank Egypt & $\mathrm{CCB}$ \\
\hline 18 & Egyptian and Arab Land Bank & $\mathrm{CCB}$ \\
\hline 19 & CITI Bank & $\mathrm{CCB}$ \\
\hline 20 & Piraeus Bank Egypt SAE & $\mathrm{CCB}$ \\
\hline 21 & Credit Agricola Bank & CCB \\
\hline 22 & HSBC Bank & $\mathrm{CCB}$ \\
\hline 23 & Barclays Bank & CCB \\
\hline 24 & African Import and Export Bank & CCB \\
\hline 25 & Bank of Alexandria and San Polo & CCB \\
\hline 26 & Banque Misr & CCBIW \\
\hline 27 & National Bank of Egypt & CCBIW \\
\hline 28 & Banque du Caire & CCBIW \\
\hline 29 & Egyptian Gulf Bank & CCBIW \\
\hline 30 & Misr Iran Development Bank & CCBIW \\
\hline 31 & Qatar National Bank Al Ahly & ICB \\
\hline 32 & Faisal Islamic Bank of Egypt & ICB \\
\hline 33 & Abu Dhabi Islamic Bank & ICB \\
\hline 34 & Al Baraka Bank Egypt & $\mathrm{ICB}$ \\
\hline 35 & National Bank of Kuwait & $I C B$ \\
\hline
\end{tabular}

Note: $\mathrm{CCB}$ - conventional commercial bank, CCBIW - conventional commercial bank with Islamic window, ICB - Islamic commercial bank. 